\title{
The identity of the recipients of the Fourth Gospel in the light of the purpose of the Gospel
}

\author{
Won-Ha Hwang \& J G van der Watt ${ }^{1}$ \\ Department of New Testament Studies \\ University of Pretoria
}

\begin{abstract}
The purpose of this article is to explore the identity of the recipients at the time of the completion of the Gospel. An effort is made to determine to whom John wrote this Gospel and how he adapted his theological message to reach this aim. It will be argued that John did not only focus on a specific group of people, but had a wide variety of people (i.e., Jews, Hellenists, Samaritans) in mind, which leads to the conclusion that the Fourth Gospel was written with both evangelistic and didactic aims.
\end{abstract}

\section{INTRODUCTION}

Contemporary Johannine scholarship attempted to establish the first readers of the Gospel within their particular situation (i.e. the Johannine community). This would create a framework for understanding the way in which John adapted his message to address their particular situation. Determining the socio-historical situation will throw some light on the reason why this Gospel was written (Ferreira 1998:26; cf Kenney 2002:9-15). For some time now, research has been conducted in an attempt to reconstruct the first historical readers; however, consensus still needs to be reached amidst notable deviations. This study will look at the cultural backgrounds of the people who were part of the Johannine community at the time the completion of the Gospel. The vocabulary, the style of writing, the distinctive use of certain concepts, and references to cultural matters may reveal valuable information about the original audience (see Van Aarde 1985:54; De Smidt 1989:58; Lombard 1989:59; 1987:395; Du Rand 1993:11).

\footnotetext{
${ }^{1}$ This article is based on the doctoral dissertation "The presence of the risen Jesus in and among his followers with special reference to the first farewell discourse in John 13:31-14:31". This dissertation, with Prof $\mathrm{Dr} J \mathrm{G}$ van der Watt as supervisor, was submitted and accepted as part of the requirements of the PhD degree (2006), Department of New Testament Studies, Faculty of Theology, University of Pretoria.
} 


\section{THE ORIGINAL READERS OF THE FOURTH GOSPEL?}

Religio-historical and socio-cultural research into early Christianity assist in proposing an intellectual framework within which the first historical readers of John's Gospel could have found themselves. For proper communication to take effect the first readers of this Gospel must have shared an intellectual framework with its author (Du Rand 1993:11; Painter 1981:527; Keener 2003:140ff; Hägerland 2003:309-322; Kenney 2002:9-15). Let us now focus on some proposals regarding the history of the Johannine community. ${ }^{2}$

Martyn has made a major contribution with his History and theology in the Fourth Gospel, first published in 1968 (see Martyn 1971, 1977) by identifying a synagogue-church drama or conflict as the crucial factor of the Gospel. According to him, the history of the Johannine community's conflict is reflected by Jesus' conflict with the "Jews". In other words, the Gospel presents a double history or drama: the experiences of the community are read back into the life of Jesus (see Ferreira 1998:31). The Gospel of John is seen as a drama presented at two levels, one concerning Jesus, situated in the early decades of the first century $C E$, the other concerning the Johannine community near the end of that century (cf Reinhartz 1998:111). To put it differently, the text should be interpreted on two levels: first, it refers to "an einmalige event during Jesus' earthly lifetime", and secondly, it refers to "actual events experienced by the Johannine church" (see Ferreira 1998:31). ${ }^{3}$ This perspective implies that John's Gospel is a Jewish-Christian composition shaped by the conflict with the synagogue. Martyn's thesis has been adopted and adapted by many scholars. In other words, since Martyn's initial publication, the field of Johannine studies has increasingly espoused the theory "that the Johannine community suffered a traumatic expulsion from the synagogue and a prolonged and violent controversy with the Jews of that synagogue" (cf Reinhartz 1998:111; Hägerland 2003:309-322).

Some years later, Culpepper addressed the social circumstances of this Johannine group in his doctoral dissertation, The Johannine School (1975). After having examined the characteristics of schools in the Hellenistic world, Culpepper (1975:287-289) concluded that the Johannine group shares nine characteristics with ancient schools: (1) the Johannine community was a

\footnotetext{
${ }^{2}$ In fact, a variety of options have been proposed on this issue. However, a detailed cataloguing and evaluation of the many theories of purpose is beyond the scope of this article. For a more comprehensive treatment of the history of interpretation of Johannine audience along with extensive bibliographies, see above all Meeks (1972:44-72); Smith (1975:222-248); Brown (1970:581-604; 1979); Hartman \& Olsson (1987:27-43); Moloney (1998b:43); Painter (1981:525-543); Beasley-Murray (1987:222-227); Bultmann (1971:457461); Schnackenburg (1982:89-93); Lindars (1972:465-469); Kysar (1992:917).

${ }^{3}$ Reinhartz (1998:111) also points out, "Attending this two-level reading strategy is the conviction that the Gospel was indeed read in this manner by its original audience, the Johannine community itself."
} 
fellowship of disciples; (2) the community gathered around, and traced its origins to a founder - the Beloved Disciple; (3) the community valued the teachings of its founder and the traditions about him; (4) members of the community were disciples or students of the founder - the Beloved Disciple; (5) teaching, learning, studying and writing were common activities in the community; (6) the community observed a communal meal; (7) the community had rules or practices regulating admission and retention of membership; (8) the community maintained some distance from the rest of the society; and (9) the community developed organisational means of ensuring its perpetuity. Culpepper's thesis gained widespread acceptance (see Ferreira 1998:30).

More recently, Brown (1979; cf 2003:74-75) presented his penetrating reconstruction of the history of the Johannine community. Brown traces four stages in the developmental history of the Johannine community: (1) Before the Gospel: At this stage, an outstanding historical personality, the Beloved Disciple and the "father" of the community, serves as link between the historical Jesus and the Johannine community. He is an ex-disciple of John the Baptist, and a follower of Jesus from the start of his ministry, but not one of the Twelve; (2) When the Gospel was written: By admitting Samaritans and other anti-Temple groups to the Johannine group, a conflict with "the Jews" ignited. The community increasingly oppose those they regard as nonbelievers; (3) When the letters were written: The community, having taken a closed stance against those outside their ranks, began to suffer from internal divisions ${ }^{4}$ (4) After the letters were written: The final moment in the history of the community is its separation and dissolution. The group behind the letters was absorbed in the second century either by the emerging great church or by groups associated with Docetism, Gnosticism, and Montanism.

On the basis of previous studies, many modern scholars hypothetically synthesised the situation of the Johannine community as follows: ${ }^{5}$ part of the

\footnotetext{
${ }^{4}$ According to Brown (2003:74-75), a study of the letters reveals at least two groups.

${ }^{5}$ Many modern scholars have other, more advanced opinions on this issue, based on previous studies. Among others, Nielsen (1999:21-22) puts the history of the Johannine community in the following way (Nielsen acknowledges that there are minor differences, insofar as some critics posit four phases. He also says that there is divergence of opinion as to how, and how sharply, the transitions between the phases are to be delineated): The history of the community can be divided into the following main three phases. First, a period in which a group of Jews lived in a religious community with other Jews, went to the synagogues, the temple and so on, the difference being their belief in Jesus as Messiah. In other words, they constituted a messianic group within the community of the synagogue. They could be referred to as Christian Jews, but they are Jews all the same. This period was brought to an end by the break that manifested itself in, among other things, the way leading Jews decided to exclude those who confessed their faith in Jesus as Messiah. In this second phase, they formed an independent community and reappeared as Jewish Christians. It was clear to all now that their Christian identity was crucial. The third phase saw the community threatened with inner schism primarily based on Christological issues. In John 9:22 and 12:42 there is evidence of the split that marks the transition from the first to the second phase, just as 16:2, for example, can be seen as characteristic of the new and tense relationship. Testimony to the third phase is found not so much in the Gospel as in the epistles, for instance, 1 John 2:18-27 and 4:1-6.
} 
survival struggle of Judaism was to turn more orthodox. After the temple and sacrifices had assumed a measure of vagueness, greater authority had to be vested in the law to keep Judaism intact. The prayer in the synagogue (Birkatha-minim), which consisted of eighteen sections (approximately 85-90 CE) contained a curse on heretics in the twelfth section, the so-called prayer against heretics in the synagogues (Du Rand 1997:64; cf Painter 1980:28-29; Nissen 1999:206-207). Therefore, the Jewish Christians, who confessed Jesus as Messiah, were cast out of the synagogues and were on occasion even killed. ${ }^{6}$ The Christians - and this included gentile Christians - felt like aliens in a hostile world. These events prompted the Johannine community to close ranks (De Smidt 1991:254; see Painter 1980:29; Kysar 1993:112; Nissen 1999:206-207). The expulsion from the synagogues took place before the Gospel was finally written down. ${ }^{7}$ This means that the author of John's Gospel was living and working in a community that found themselves in a crucial dispute with their local synagogues. Even after their physical and theological separation from the synagogue, it seems as if they were still persecuted. The Gospel of John was written within this context ${ }^{8}$ and the aim of the author was the well being of the community (Van Aarde 1985:59). This he did by consistently maintaining his basic theological perceptions and accents (De Smidt 1991:254). The author directed and shaped his message with this social reality of the recipients in mind (De Smidt 1989:248; Hägerland 2003:309-322).

Due to the fact that the author does not expressly name his intended readers in the text itself, any attempt to identify the first readers of this Gospel is obviously hypothetical (see Du Rand 1997:42f). However, new efforts were made in the 1980's to reconstruct the socio-historical setting of the Fourth Gospel (see Van der Merwe 1995:69-70). Painter (1980:22) argued that are no straightforward indications upon which a history of this community could be reconstructed although there are some clear hints. Indeed, many scholars emphasize the hypothetical nature of any endeavour to reconstruct a sociohistorical background of the Fourth Gospel, owing to the fact that no explicit,

\footnotetext{
${ }^{6}$ According to this theory, the narrative of the healing of the man born blind is yet another of John's devices for identifying his church. Scholars who defend this opinion argue that the two communities are distinct. For them, the reluctance of the man's parents to commit themselves by refusing to affirm the healing serves to elucidate this distinction (9:22).

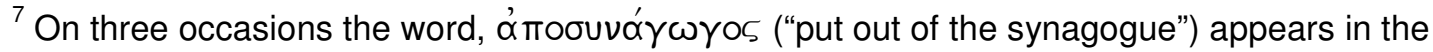
Gospel (9:22; 12:42; and 16:2). Scholars who follow this theory propose that such references reflect the time and situation of the author and his community and not that of the historical Jesus (see Kysar 1992:918).

${ }^{8}$ Within this scenario, the "terminus ad quem" of this Gospel is possibly 100-110 AD and therefore it can be accepted that the community must have been an independent and advanced community at that time, i.e. the post-apostolic period (cf Kysar 1975:261; Brown 1984:84).
} 
straightforward information is available or accessible. In any case the composition of the Gospel stretched over sixty years (Painter 1980:22; cf Van der Watt 1991:94; Becker 1981:173). A wide variety of opinions and suggestions therefore exist (Van der Merwe 1995:70). For example, Ashton (1991:163) criticises Boismard for having too many weak links in his long and elaborate hypothesis of the development of the community. Kysar (1977:356ff) thinks Cullmann's view comes close to a dogmatic hypothesis. Brown (1979), in self-reflection, mentioned that he would be grateful if only one third of this hypothesis was accepted. This indicates that scholars who worked on the socio-historical background of the Fourth Gospel were very aware of the hypothetical nature of their constructions.

\section{RECIPIENTS IMPLIED FOR THIS GOSPEL}

The hypothetical nature of this endeavour does not imply that no effort should be made at all to reconstruct the historical setting to John's Gospel. Although contemporary scholarship is not unanimous in its view, a certain measure of agreement does exist (see Brown 2003:74-75; Keener 2003:140ff). One such aspect is that the text offers important information in this regard. In other words, modern readers of the Gospel must rely on ancient texts to provide a window into the setting in which the Gospel was composed and first read (Koester 2003:18-24). Aspects like the vocabulary, the style of writing, a distinctive use of certain concepts, and reference to cultural matters may all furnish information about the original audience of this Gospel (Du Rand 1993:11; De Smidt 1989:58; Lombard 1989:59; 1987:395; Van Aarde 1985:54; Painter 1981:527; Keener 2003:140ff; Kenney 2002:9-15; Domeris 1988:49-56). That is, John offers certain explanations $(3: 1 ; 11: 1$; etc) or identify the location of events $(5: 2 ; 11: 18,54$; see Du Rand 1997:56-61; Ferreira 1998:26ff). ${ }^{9}$ Such comments and clarifications could also have been

\footnotetext{
${ }^{9}$ Bultmann (1971:35ff) initially suggested that the Gospels are sources for the situations from which they arose and only secondary sources for the historical situations they describe. His opinion paved the way for the belief that the teaching of the Fourth Gospel, in a certain sense, mirrors the situation of the author and of the Johannine community (see Van der Merwe 1995:68). In this article it will be argued that the final form of the Gospel presupposes a spectrum of readers who came from various backgrounds. The Gospel would have been accessible to the less-informed readers yet sophisticated enough to engage those who were better informed. Koester (2003:19), following Brown (1979:25-58) and Schnackenburg (1982:203-217), properly argues that there are two types of reasons for thinking that the final form of John's Gospel presupposes a spectrum of readers: first, literary studies have pointed out that some portions of the Gospel assume that readers are well informed about Jewish festivals like Passover and the Feast of Booths, and that they can follow intricate debates based on the Scriptures and Jewish traditions. Yet other passages assume that some readers are not so well informed, patiently interpreting the meaning of words like rabbi and messiah $(1: 38,41)$, and explaining that Jews used stone jars for purification rituals and did not associate with Samaritans $(2: 6 ; 4: 9 \mathrm{~b})$. The tension between passages presupposing a highly informed readership and those addressed to a less informed readership suggests that the audience of the completed Gospel included various types of people (Culpepper 1983:221, 225). Second, historical studies have shown that the Gospel and the community in which it was composed, developed over a period of time. Although the literary history of the text and the social history of the community cannot be reconstructed with certainty at each juncture, it seems probable that the final form of the Gospel engaged Christians of different backgrounds: Jewish, Samaritan, and Greek.
} 
added over a longer period to assist new groups of readers. In other words, the original, predominantly Jewish-Christian group of readers could have been expanded over time through the addition of converts from the world of Greek paganism (Du Rand 1993:17; Ashton 1991:102; Koester 2003:19-24; Keener 2003:140-232).

The particular vocabulary, the style of writing, the distinctive use of certain concepts, and reference to cultural matters provide plausible grounds for concluding the following (see Koester 2003:19-24; Witherington III 1995:32-35): ${ }^{10}$

Jewish Christians were almost certainly at the centre of the audience for whom John's Gospel was written (see Keener 2003:171-232). The opening scenes present Jesus as a rabbi and as the Messiah or "Christ" foretold in the Jewish Scriptures. The titles "Son of God" and "King of Israel" also recall Jewish traditions (1:35-51). Jesus continues to be called a rabbi throughout the Gospel, suggesting that the title was significant for readers, and the evangelist seems to use "Christ" as a Jewish messianic expression rather than making "Christ" a part of Jesus' name. ${ }^{11}$ Jesus' identity is also explicated in terms of the Jewish festivals of the Sabbath, Passover, Booths, and Dedication or Hanukkah (John 5-10), and the major symbols in these chapters - bread, water, and light - are closely connected to their use in Jewish rituals at these festivals (see Witherington III 1995:32-33). ${ }^{12}$ In particular, John's original audience seems to have consisted primarily of Diaspora Jews and

\footnotetext{
${ }^{10}$ The sketch of Johannine Christianity presented here closely follows that formulated by Brown (1979:25-28) and developed by Koester (2003:19-24).
}

${ }^{11}$ There are seven cases of translations or explanation of Hebrew or Aramaic terms, some of which, like "rabbi" or "messiah," must surely have been familiar to even Diaspora Jews (cf $1: 38,41,42 ; 9: 7 ; 19: 13,17 ; 20: 16)$. If these sorts of explanations were in the source John drew on and he did not think the audience would need such explanations, it is hard to explain why he would have left them in the text. As Witherington III (1995:32) thinks, the paradigmatic readers assume they tell something about the audience John was addressing.

\footnotetext{
${ }^{12}$ According to Koester (2003), the readers of the Gospel who came into the Christian community from the synagogue would have been a part of the broad section of the Jewish population that was influenced by the teachings of the Pharisees and the rabbis without actually belonging to a Jewish party. For him, although there are affinities between John's Gospel and some of the Dead Sea texts - such as the dualistic use of light and darkness the Gospel does not allude to any teachings peculiar to the Dead Sea sect, and there is little reason to think that the Johannine community included members from this group. Moreover, he argues that Jesus is pictured as teaching "in synagogues and in the temple, where all Jews come together" (18:20), and some of the symbols assume that many of the readers would have been familiar with temple ritual; but the members of the Dead Sea sect did not gather in synagogues used by other Jews and they actually boycotted the Jerusalem temple. He suppose that John's Gospel, unlike the other Gospels, never mentions the Sadducees or any of their distinctive teachings, but simply assumes the importance of the prophetic writings and Psalms and belief in resurrection, which the Sadducees did not acknowledge. Koester (2003) looks for texts that reflect views that were commonly held among Jewish people in the first century and were not limited to one Jewish party.
} 
proselytes (Carson 1991:91; Köstenberger 2004:8; Keener 2003:171-232; Domeris 1988:49-56). The central conflict in the Gospel involves the Jewish authorities on one hand and Jesus and his followers on the other (Painter 1981:527; Lincoln 2002:3-26; Schneiders 1998:513-535). Especially significant is the story of the man born blind, who was repeatedly questioned concerning Jesus by some of the Jewish leaders and who was eventually expelled from the local synagogue (9:22). Conflict with and fear of expulsion from the synagogue were apparently significant influences in the construction of this Gospel. John cited fear of expulsion from the synagogue as one of the main reasons for the refusal of people to confess their faith in Christ (12:42). Moreover, the farewell discourses explicitly forewarned that Christians would continuously be threatened by expulsion even after Jesus had returned to the Father (16:2).This suggests that the experience of Jewish Christians in the post-resurrection period corresponds with the experience of the man born blind (Koester 2003:20; Witherington 1995:32-34). Apparently, both the Jewish opponents as well as the Johannine community were apparently closing ranks and were defending themselves. Within this milieu the Gospel of John took shape (Van der Watt 2001:8). ${ }^{13}$ As such the Gospel was primarily aimed at the edification of the Johannine community in this conflict situation (Beasley-Murray 1987:387). In other words, the Gospel of John was addressed to believers in order to strengthen their faith in the midst of a critical situation that could have developed and influenced them over a lengthy period (cf Kysar 1992:917). ${ }^{14}$

Apart from these Jewish Christians, it seems plausible that people of Samaritan decent were also part of the Johannine community (see Koester 2003:20-21; Keener 2003:140-232). According to John 4, a village of Samaritans was converted through the witness of a woman. This remarkable episode seems to presuppose future missionary activity of the disciples in this region. Although the disciples played no role in bringing the Samaritan villagers to faith in this episode, Jesus spoke proleptically as if they had already engaged in successful missionary activity, "I sent you to reap that for which you did not labour; others have laboured, and you have entered into their labour" (4:38). External evidence suggests that Jesus either avoided Samaria or was unwelcome there during his lifetime, but that after his resurrection Christians did engage in missionary activity in Samaria (Ac 8:4-

\footnotetext{
${ }^{13}$ This indicates that the Gospel is rooted in the particular situation obtaining in this particular community and deals with their unique religious and theological problems (cf Culpepper 1975:262).

${ }^{14}$ Still the attention to the nurturing of faith in the farewell discourses (Jn 14-17), the concern for apostasy (e.g., 6:60-69), and attention to the theme of the quality of sound faith (e.g., 4:4353; 6:25-27; 20:29) contribute decisively to that impression (Kysar 1992:918).
} 
25). ${ }^{15}$ The detailed knowledge of Samaritan topography apparent in the Fourth Gospel could suggest that Johannine Christians were at some point active in Samaria. The narrative refers to Sychar, and rightly assumes that Jacob's well was located by a road that skirted the grain fields and that it was within eyesight of "this mountain", Mount Gerizim, where the Samaritans worshipped (Jn 4:20,35). The Gospel also mentions the area of Aenon near the village of Salim (3:23) and a town called Ephraim (11:54), both of which were probably in the region of Samaria (Koester 2003:20-21). ${ }^{16}$

The Greeks only appear at the culmination of the Johannine account of Jesus' public ministry in Chapter 12. As Jesus approached Jerusalem on a donkey with the crowds waving palms around him, the Pharisees lamented, "You see that you can do nothing; look, the world has gone after him". The author immediately comments that "among those who went up to worship at the feast were some Greeks" (12:19-20). Since these Greeks came to Jerusalem for the festival, it is plausible that they could have been proselytes; yet there are good reasons for the suggestion that they symbolically represent gentile interest in Jesus. The use of the term Greeks, which regularly designated non-Jews in sources of this period, and their arrival at precisely the moment when the whole "world" was going after Jesus, indicate that they should be understood to be people of non-Jewish background (see Brown 1979:55-58). Significantly, these Greeks, unlike the Jewish people mentioned earlier in the narrative, did not actually get to see Jesus. Instead, they approached Philip (12:21-22), who conveyed their request to Jesus. Jesus announced that the arrival of the Greeks signalled the hour of his glorification, when he would be lifted up in death to draw "all people" to himself $(12: 23,32-$ 33). The sign above the cross proclaimed Jesus' kingship in Greek, Latin and Hebrew (19:20), reaffirming the significance of his death for both Jews and non-Jews. Although the Greeks who appeared in Chapter 12 did not get to see Jesus before he was lifted up, the text looks beyond Jesus' death and resurrection to the time when Greeks would be drawn to Jesus through the work of disciples such as Philip, whom Jesus would send into the world (17:18-21). Other sources seem to suggest that the proclamation of the Gospel to the Greeks was not a feature of Jesus' own ministry, but of early Christian missionary work. Some years after Jesus' resurrection, the Christian message was extended to the Greeks at Antioch (Ac 11:20-21), and congregations that included Greeks were gradually formed at many places in the Mediterranean world. An apparent allusion to this missionary activity

\footnotetext{
${ }^{15}$ On Jesus and his disciples avoiding Samaria see Mt 10:5; Lk 9:52-53; 17:11. A more positive view of the Samaritans is reflected in Luke 10:33, 17:11-19.

${ }^{16}$ Koester (2003:21) notes: "There are few extant Samaritan sources from this period; apart from the Samaritan version of the Pentateuch, the Samaritan texts we have are from the fourth century and later."
} 
among the Greeks is found in John 7:35, where the Jewish opponents, who were puzzled by Jesus' remarks about going to the one who sent him, asked, "Surely he doesn't intend to go to the Dispersion among the Greeks and teach the Greeks, does he?" Their question refers to the dispersion of Jews living outside Palestine in regions where most of the population would be considered Greek, which would include the area from Macedonia and Greece through Asia Minor and into Syria (cf Mk 7:26). Grammatically, the Pharisees' rhetorical question expects a negative answer, which would be correct in a sense, since Jesus was not speaking about a trip around the eastern Mediterranean but of his return to God. Yet in another sense their question actually demands a positive answer, since after Jesus returned to God he would "teach the Greeks" through the work of his disciples (Koester 2003:2023). ${ }^{17}$

\section{RECIPIENTS AND THE PURPOSE OF THE GOSPEL}

The present form of the Fourth Gospel seems to envision a spectrum of implied readers. The brief analysis above showed that Jewish Christians formed the core of the audience for whom the Gospel was written (see Smith 1986:83-86; Witherington III 1995:29-35; Keener 2003:140-232). The audience was not limited to them, but also included various other groups (i.e. Jewish, Samaritan, and Greek - in the wider sense of the word - groups). These observations will now be linked to the purpose of the Gospel. The issues of the original recipients and the purpose of the Gospel are indeed closely related (Du Rand 1997:49). ${ }^{18}$

The purpose of the Gospel according to John is a well-discussed issue in Johannine research (see Carson 1987:639-651; Brown 2003:151-188). In comparison to the Synoptics, the distinctive character of this Gospel, in terms of content, perspective, vocabulary, style and so on, ask immediate attention (cf Ferreira 1998:26). However, various proposals on the purpose and

\footnotetext{
${ }^{17}$ The Greeks in the audience envisioned by the evangelist cannot be firmly identified with a distinctive philosophical school or religious group. The Gospel's references to logos, freedom, and friendship, for example, have affinities with Stoic and Platonic teachings, but all of these concepts had fairly wide currency and none was limited to one philosophical school. Significantly, many aspects of the Gospel show a broad familiarity with Greco-Roman culture. The author divided scenes, portrayed characters, and used dramatic irony in ways similar to the Greek tragedians and followed Greco-Roman rhetorical patterns in some of the discourses (Koester 2003:23).

${ }^{18}$ In this regard, Nielsen (1999:21) states, "it is primarily on the basis of the present Gospel that it is possible to form an idea of the history of the community/school and its relation to the origin of the Gospel." Kysar (1992:917) also notes, "equally significant in determining the precise purpose of the Gospel is the supposed situation out of which and for which it was written".
} 
intention of the Gospel of John are indeed myriad. ${ }^{19}$ Despite the fact that a whole chapter (chapter 21) follows on the suggested statement of the purpose in 20:30-31, ${ }^{20}$ a large measure of consensus exists that $20: 30-31$ should indeed be seen as the explicit statement of the purpose of the Gospel (see Brown 1970:1057; Van Belle 1998:300-325; Mlakuzhyil 1987:167; Carson 1991:665). ${ }^{21}$ According to 20:30-31 the purpose for writing the Gospel focuses on the person of Jesus: it is an account of his "signs", so that people would believe in him and thus receive eternal life in him (Witherington III 1995:30; Burridge 1991:236). This is an unequivocal statement of the central purpose of the book: to foster faith in Jesus as the Messiah, the Son of God, resulting in eternal life (Blomberg 2001:271; Van der Watt 1989:217-228). John encourages and strengthen a certain kind of belief in and about Jesus among his readers. These sorts of didactic and evangelistic aims were common in ancient biographies, especially those originating in philosophical schools, and those that had certain rhetorical aims through the art of persuasion (Burridge 1991:237). It seems very plausible that a good deal of the content of this Gospel was constructed so as to be making it suitable for use in the debate with opponents as well as possible converts (Witherington III 1995:30).

\footnotetext{
${ }^{19}$ A detailed cataloguing and evaluation of the many theories of purpose is beyond the scope of this article. For a fuller treatment of the history of interpretation of Johannine purpose along with extensive bibliographies see Brown (2003:151-188); Wind (1972:26-69); Smalley (1978:122-138) and Du Rand (1997:49-55).

${ }^{20}$ There is a serious argument whether the body of the Gospel comprises the end of John 20 and the whole chapter of John 21 should be regarded as an appendix, which means that John 21 was not part of this Gospel as it was originally written (see Mlakuzhyil 1987:89; Smalley 1978:138; Morris 1971:858-859; Blomberg 2001:272-273; Brown 1970:1077-1082; Ridderbos 1997:655-658; Keener 2003:1213). The diachronic development of the text is however beyond the scope of this article, and only the final form of the text is considered. The only suggestion here is that the statement in John 20:30-31 is skilfully intended by the author as formulation of his (provisional) purpose for the Gospel as a whole.

${ }^{21}$ The following are some remarks on the literary identity of John 20:30-31 as stating the conclusion and purpose of the Gospel: Newman and Nida (1980:620) state, "It is the consensus of New Testament scholars that these two verses form the original conclusion to the Gospel." Schnackenburg (1982:335) says, "There remains no doubt that this is the original end of the work and chapter 21 is a postscript from whomever its content might come." He goes on to mention, "The conclusion in John 20:30-31 is intended, above all, to point out clearly the purpose of the writing." Bultmann (1971:697) states, in unambiguous terms, "20:30f is a clear conclusion to the Gospel, in which the selective character of the narrative is stressed and its purpose declared." Barrett (1978:575) notes, "Both the purpose of the Gospel and the author's theology are summed up in this verse." Brown (1970:1057; 2003:180) claims, "The air of finality in these two verses justifies their being called a conclusion despite the fact that in the present form of the Gospel a whole chapter follows." He $(1970: 1057 ; 2003: 180)$ also underscores, "Of all the Gospels John is the most articulate about its purpose in the statement of John 20:30-31." Witherington III (1995:29) notes, "Quite naturally, the discussion of purpose in regard to the Fourth Gospel always begins with, and frequently gets no farther than, the discussion of John 20:31." More recently, Culpepper (1998:244) states, "The last two verses of John 20 appear to provide a suitable ending for the Gospel."
} 
However, a well known Johannine question is whether the Gospel was written to bring people to faith or to strengthen the faith of those who already believe, inter alia because of the textual variant in 20:31 (Van der Watt 2002:93; see Thompson 1992:372; Keener 2003:1215-1216; Carson

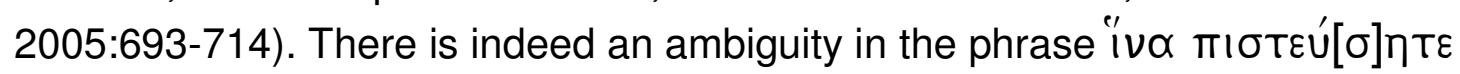
("that you may believe"), and it is compounded by uncertainty as to whether

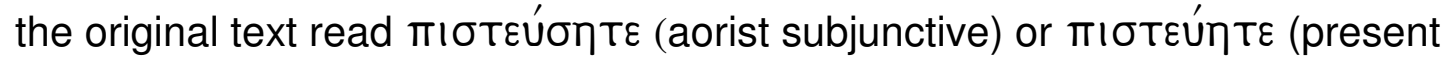
subjunctive) (Metzger 1994:219-220; cf Beasley-Murray 1987:Ixxxviii; 387; Bruce 1983:396; Barrett 1978:114; Kysar 1993:19). The former (aorist subjunctive) is attested by $\aleph^{2} A C D L W \Psi_{f}^{1.13}$ et alia, while the latter (present subjunctive) is supported by $\mathrm{P}^{66 \mathrm{vid}}{ }^{\star}{ }^{*} \mathrm{~B} \theta 0250$ et alia. Thus the external evidence for the aorist subjunctive or the present subjunctive is very finely balanced and accordingly textual attestation is inconclusive. According to Metzger (1994:219-220), the aorist tense, strictly interpreted, suggests that the Fourth Gospel was addressed to non-Christians so that they might come to believe that Jesus is the Messiah; the present tense suggests that the aim of the writer was to strengthen the faith of those who already believe ("that you may continue to believe"). ${ }^{22}$ To put it more precisely, the former could suggest inviting people to faith, the latter encouraging people to continue in their faith; the former thus implies an evangelistic purpose, the latter an instructional or paraenetic purpose; the former that the Gospel was directed at outsiders (unbelievers), the latter that it was directed at those within the church (believers- see Brown 2003:180; Carson 1991:90, 2005:694-714; Morris 1971:40; Witherington III 1995:29-32). Since difference in opinion exists on the form of the Greek verb the question is not answered conclusively yet (see Brown 2003:182ff). ${ }^{23}$ Does John want to win non-believers to faith in

\footnotetext{
${ }^{22}$ Metzger (1994:219-220) states, "in view of the difficulty of choosing between the readings by assessing the supposed purpose of the evangelist (assuming that he used the tense of the subjunctive strictly), the Committee considered it preferable to represent both readings by enclosing $[\sigma]$ within square brackets."

${ }^{23}$ The majority of recent commentators probably prefer the present subjunctive tense and accordingly have proposed that the primary purpose of the Gospel is related to encouraging, sustaining, or instructing believers (see Smith 1986:83-86; Strachan 1941:41). Brown is one of the prominent scholars who insist that the Gospel was written to intensify people's faith and make it more profound (see 2003:152). He (2003:182) puts his position more precisely as follows: "Certainly the Gospel was written in good part to deepen the faith of believers so that they could understand that what they had gained by way of God's life more than made up for what had been lost in their former religious adhesion. The evangelist speaks to those who accepted Jesus, thereby becoming God's children, begotten not by human intervention but by God (1:12-13), in order to make them appreciate the life they had been given. Some of the decisive theological emphases in the Gospel are directed to crises within the believing community, rather than to the conversion of non-believers." Brown (2003:183) also notes, "As for bringing people to faith, there is not much evidence that the Gospel was a missionary document in the ordinary sense of offering a text to be read to or by non-believers. Yet John manifests a conviction that if the faith of believers is intense, thereby others will gain knowledge about Jesus. In that sense those who possess the Paraclete become witnesses to Jesus (15:26-27). When believers share Jesus' glory by becoming one with God and Jesus, the world will come to know that God sent Jesus as a manifestation of love (17:22-23). Thus John's primary purpose of deepening the faith of believers has a secondary goal of thereby bringing others to make an act of faith." On this position, Van der Merwe (1995:71; cf Barrett 1978:116) states, "From these studies a new trend becomes clear, namely, movement away from a hypothetic constructed Johannine community."
} 


\section{The identity of the recipients of the Fourth Gospel}

Christ, or is his purpose to strengthen believers in their faith? The answer to this question will directly impact on the question of the nature of the originally intended readership. Who were the "you" in "that you may have faith that Jesus is the Messiah, the Son of Man" (cf Brown 2003:180)?

As was already pointed out, no conclusive answer seems possible when only the textual (that is, grammatical) or syntactical considerations are taken into account. Are there other considerations that could shed some light on the problem? It is suggested here that an answer to this question could be attempted by taking the rhetoric and contents of the entire Gospel into account. Focus will first fall on literary considerations followed by some remarks about the socio-historical investigation of the actual audience of the Gospel.

Taking the possible identity of the original recipients of the Gospel into account as it is discussed above, the following observations could be made:

1) Since Jewish Christians were almost certainly at the centre of the audience for the Gospel was written, it is plausible to suppose that the Gospel was primarily written to intensify people's faith and make it more profound (Brown 2003:152). ${ }^{24}$ Why do they need strengthening? - because they have been challenged and confronted by those who do not accept Jesus and were excluded from the synagogue(s). Confronted with this situation an apologetical and polemical tone were to be expected (Brown 2003:152). This type of rhetoric reflects controversies in the community's history and serves to reinforce those who believe in Jesus (see Du Rand 1997:55).

2) However, the idea that the Gospel narrative aims at engendering faith in non-believers equally forms part of the rhetorical purpose of the Gospel. A selection of the signs of Jesus throughout the Gospel will enable the reader to understand the real identity of the Gospel's central

\footnotetext{
${ }^{24}$ Scholars have thus been increasingly inclined to believe that the Gospel was written for the edification of Christians. Culpepper (1998:244) supports this proposal, with the statement, "Seen in a larger context, the Gospel as a whole appears to have been written primarily for the believing community, to provide ready material for telling the church's story for those who do not believe. John clarifies the reasons for unbelief and explores various misunderstandings and stages of faith (cf $\mathrm{Jn} \mathrm{5}$ ). It also reflects a rhetorical strategy that leads the reader to embrace the narrator's affirmation of Jesus as the Christ (cf Jn 4)." Kümmel (1973:229) also remarks, "It is extremely unlikely that the author of [the Gospel] is thinking primarily of nonChristians .... Thus [John] was written, at least primarily, to confirm and secure Christians in the faith." Du Rand (1997:55) consents: "The aim is that the Christians as first historical readers should be encouraged to continue to believe that Jesus, the Messiah, is the Son of God. The Gospel of John is (in his view) thus not primarily a missionary writing that endeavours to bring people to faith, but rather its intention is to strengthen their faith."
} 
figure, and by faith in him to receive the eternal life (cf 20:30-31). ${ }^{25}$ Thus, the written word counts as the medium through which faith is mediated (Van Belle 1998:305). Instead of physically hearing the words from the mouth of Jesus himself or seeing him performing signs (as his first followers could), the present day reader is confronted with these words and actions of Jesus through the text (cf Moloney 1998:538). The text of John's Gospel thus becomes the "presence of Jesus" among the readers and should be read as a challenge to the reader to the point where Jesus is accepted as Christ and an existential change takes place in the life of the believer, from death to life (cf 5:25;20:31) (Van der Watt 2002:91).

\section{CONCLUSION}

Although it seems that the main aim of the author is to strengthen the faith of those who already believe, a secondary aim, namely of bringing others to faith in Jesus, should not be excluded. As Van der Watt (2002:93) argues, there is ample evidence in the Gospel that it invites people to believe, but equally convincing evidence that the Gospel wants to strengthen the faith of believers. Thus, it is reasonable to conclude that the Fourth Gospel was written with both evangelistic and didactic aims in view. This suggests not only a Jewish Christians readership but a much wider audience, including Samaritans and Greeks. Some were already part of the Johannine community, while others were still potential believers - the Gospel was written for all of them.

\footnotetext{
${ }^{25}$ Such is the conviction of several, among whom Beasley-Murray, who does not support a decision of the aim depending on a fine point of Greek grammar, not least in view of the fact that John does not always keep the rules in his use of tenses, may be cited as a representative (Beasley-Murray 1987:387). According to Beasley-Murray (1987:388), the Gospel of John, like the Bible as a whole, was written for the sake of the people of God, and it has been preserved by them through the centuries. However, he argues that the Bible is also a very powerful witness to the Christian faith for non-believers, and so is the Gospel of John, as a multitude of evangelistic agencies have experienced. Thus he proposes that the primary and the secondary purposes run close together. In the view of Beasley-Murray (1987:Ixxxix), John attempted and achieved the essential task of setting forth the faith once delivered to the saints in the new idiom, for the winning of new converts to the church, for the strengthening of those who were unsettled by the new winds of doctrine, and for the more adequate exposition of the faith itself. Kysar also defends this theory. According to him (1993:19), John 20:31 has the double scope or purpose of the writer, namely, that the readers may believe in Jesus as the Christ and the Son of God and, continuing to believe, may have eternal life. This attempt is closely related to the universalism of the Gospel. Brown (2003:181) notes: "As part of John's universalism, we are told that Jesus comes into the world as a light for everyone (1:9). Jesus takes away the sins of the world (1:29); and he was sent that the world might be saved through him (3:17). Jesus was to die not only for the Jewish nation, but also to gather together the dispersed children of God and make them one (11:51-52). When he is lifted up on the cross and in resurrection/ascension, he draws all to himself (12:32)." He goes on to say, "Jesus is the Lamb of God who takes away the sin of the world (1:29), the Saviour of the world $(4: 42)$, the bread from heaven that gives life to the world $(6: 33)$, the light of the world $(8: 12 ; 9: 5 ; 12: 46)$. In Johannine expectation is the access of the world closed with the judgement of the world that took place in the defeat of the Prince of this world by the lifting up of Jesus (12:31-32)."
} 


\section{Works consulted}

Ashton, J 1991. Understanding the Fourth Gospel. London: Oxford University Press.

Barrett, C K [1955] 1978. The Gospel according to St John: An Introduction with commentary and notes on the Greek Text, rev ed. London: SPCK.

Beasley-Murray, G R 1987. John. Waco, TX: Word Books.

Becker, J 1981. Das Evangelium nach Johannes: Kapitel 11-21. Würzburg:

Gütersloher Verlagshaus. (Ökumenischer Taschenbuchkommetar zum Neuen Testament 4.)

Blomberg, C L 2001. The historical reliability of John's Gospel: Issues \& commentary. Downers Grove, IL: Inter Varsity Press.

Brown, R E 1970. The Gospel according to John, vol II: Chapters 13-21. New York: Doubleday.

Brown, R E 1979. The community of the Beloved Disciple: The life, loves and hates of an individual church in New Testament times. London: Geoffrey Chapman.

Brown, R E 1984. The churches the apostles left behind. London: Chatman.

Brown, R E 2003. An Introduction to the Gospel of John, edited and updated by F J Moloney. Now York: Doubleday.

Bultmann, R 1971. The Gospel of John: A commentary, tr by G R Beasley-Murray. Oxford: Basil Blackwell.

Burridge, R A 1991. What are the Gospels? Cambridge: Cambridge University Press.

Carson, D A 1991. The Gospel according to John. Grand Rapids, MI: Eerdmans.

Carson, D A 2005. Syntactical and text-critical observations on John 20:30-31: One more round on the purpose of the Fourth Gospel. JBL 124(4), 693-714.

Culpepper, R A 1975. The Johannine School: An evaluation of the Johannine School hypothesis based on an investigation of ancient schools. Missoula, MT: Scholars Press.

Culpepper, R A 1983. Anatomy of the Fourth Gospel: A study in literary design. Philadelphia, PA: Fortress.

Culpepper, R A 1998. The Gospel and Letters of John. Nashville, TN: Abingdon.

De Smidt, J C 1989. Die Johannesevagelie en die "sakramente": Die eksegese van Johannes 3:3-7, 22-25 en 6:22-59. D Th-proefskrif, Universteit van SuidAfrica.

De Smidt, J C 1991. A perspective on John 15:1-8. Neotestamentica 25(2),251-272.

Domeris, B 1988. Christology and community: A study of the social matrix of the Fourth Gospel. JTSA 64, 49-56.

Du Rand, J A 1993. The Gospel according to John: Introduction and theology (Introduction to the Gospel of John), in Du Toit, A B (ed), Guide to the New Testament, vol VI: The Gospel of John; Hebrews to Revelation, 1-39. Pretoria: NG-Kerkboekhandel.

Du Rand, J A 1997. Johannine perspective: Introduction to the Johannine writings, Part I. Johannesburg: Orion.

Ferreira, J 1998. Johannine ecclesiology. Sheffield: Sheffield Academic Press. (JSNT SS 160.)

Hägerland, T 2003. John's Gospel: A two-level drama. JSNT 25(3), 309-322.

Hartman, L \& Olsson, B 1987. The history of the Johannine movement, in Hartman, $L$ \& Olsson, B (eds), Aspects on the Johannine literature, 27-43. Uppsala:

Almqvist \& Wiksell. (ConBNT 18.)

Keener, C S 2003. The Gospel of John. Peabody, MA: Hendrickson. 
Kenney, G C 2002. Leadership in John: An analysis of the situation and strategy of the Gospel and the Epistles of John. Lanham, MD: University Press of America.

Koester, C R [1995] 2003. Symbolism in the Forth Gospel: Meaning, mystery, community, 2nd ed. Minneapolis, MN: Fortress.

Köstenberger, A J 2004. John. Grand Rapids, MI: Baker Academic.

Kümmel, W G 1973. The Theology of the New Testament: According to its major eitnesses Jesus-Paul-John, tr by E S John. Nashville, TN: Abingdon.

Kysar, R [1976] 1993. The Maverick Gospel, rev ed. Louisville, KY: Westminster John Knox.

Kysar, R 1975. The Fourth evangelist and his Gospel. Minneapolis, MN: Augsburg.

Kysar, R 1977. Community and Gospel: Vectors in Fourth Gospel criticism. Interpretation 31, 355-366.

Kysar, R 1992. John, the Gospel of, in Freedman, D N (ed), Anchor Bible Dictionary, vol 6, 912-931. New York: Doubleday.

Lincoln, A T 2002. The Beloved Disciple as eyewitness and the Fourth Gospel as witness. JSNT 85, 3-26.

Lindars, B 1972. The Gospel of John. London: Marshall, Morgan \& Scott.

Lombard, H A 1987. John's Gospel and the Johannine Church: A mirror of events within a text or/and a window on events within a church. HTS 43, 395-413.

Lombard, H A1989. Ondersoek na 'n Johannese kerk/skool. HTS 45, 59-78.

Martyn, J L [1968] 1979. History and theology in the Fourth Gospel. Nashville, TN: Abingdon.

Martyn, J L 1971. Source criticism and religiousgeschichte in the Fourth Gospel, in Ashton, J (ed), The interpretation of John, 99-121. Philadelphia, PA: Fortress.

Martyn, J L 1978. Glimpses into the history of the Johannine community: From its origin to the period of its life in which the Fourth Gospel was composed, in de Jonge, M (ed), L'Evangile de Jean, 149-176. New York: Harper \& Row.

Meeks, W A 1972. The man from heaven in Johannine Sectarianism. JBL 91, 44-72.

Metzger, B M 1994. A textual commentary on the Greek New Testament: A comparison volume to the UBS ${ }^{4}$. New York: United Bible Society.

Mlakuzhyil, G 1987. The christocentric literary structure of the Forth Gospel. Roma: Editrice Pontificio Istituto Biblico.

Moloney, F J 1998. John. Collegeville, MN: The Liturgical Book.

Newman, B M \& Nida, E A 1980. The Handbook on the Gospel of John. New York: United Bible Society.

Nielsen, H K 1999. Johannine Research, in Nissen, J, Pedersen, S (eds), New readings in John: Literary and theological perspectives. Essays from the Scandinavian Conference on the Fourth Gospel on Arhus 1997, 11-30. Sheffield: Sheffield Academic Press. (JSNT SS 182.)

Nissen, J 1999. Community and ethics in the Gospel of John, in Nissen, J \& Pedersen, S (eds), New readings in John: Literary and theological perspectives. Essays from the Scandinavian Conference on the Fourth Gospel on Århus 1997, 194-212. Sheffield: Sheffield Academic Press. (JSNT. SS 182.)

Painter, J 1980. Glimpses of the Johannine community in the rarewell discourse. $A B R$ 28, 21-38. 
Painter, J 1981. The farewell discourses and the history of the Johannine christianity. NTS 27(4), 525-543.

Rabinowitz, P J 1977. Truth in fiction: A reexamination of audiences'. Critical Inquiry 4, $121-141$.

Schnackenburg, R [1975] 1982. The Gospel according to St John, vol 3: Commentary on chapters 13-21, tr by C Hastins, F McDonagh, D Smith \& R Foley. London: Burns \& Oates.

Schneiders, S M 1998. "Because of the woman's testimony ....": Reexaminating the issue of authorship in the Fourth Gospel. NTS 44, 513-535.

Smalley, S S 1978. John: Evangelist and interpreter. London: The Paternoster Press.

Smith, D M 1975. Johannine Christianity: Some reflections on its character and delineation. NTS 21, 222-248.

Smith, D M 1986. John. Philadelphia, PA: Fortress.

Thompson, M M 1992. The Gospel of John, in Green, J B \& McKnight, S (eds), Dictionary of Jesus and the Gospels, 368-383. Downers Grove, IL: Inter Varsity Press.

Van Aarde, A G 1985. Die outeurskapsvraagstuk van die Johannesevangelie met die oog op interpretaise of resepsie. Skrif en Kerk 6, 45-62.

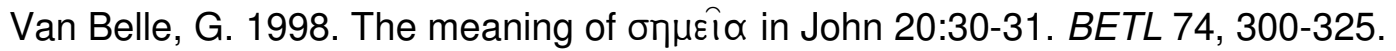

Van der Merwe, D G 1995. Discipleship in the Forth Gospel. DD Thesis, University of Pretoria.

Van der Watt, J G 1989. The use of 'AI $N N I O \equiv$ in the concept $Z \Omega H$ ' $A I \Omega N I O \equiv$ in John's Gospel. Novum Testamentum XXXI (3), 217-228.

Van der Watt, J G 1991. Die Woord het mens geword: " $n$ Strukturele uiteensetting van die teologie van die Johannesevangelie, in Roberts, $\mathrm{J} \mathrm{H}$, Vorster, W S, Vorster J N, Van der Watt, J G (reds), Theologie in konteks, 93-130. Pretoria: Orion.

Van der Watt, J G 2001. Exegesis: An approach. Unpublished lecture syllabus, University of Pretoria.

Van der Watt, J G 2002. The presence of Jesus through the Gospel of John. Neotestamentica 36(1-2), 89-95.

Wind, A 1972. Destination and purpose of the Gospel of John. Novum Testamentum 14, 26-69.

Witherington III, B 1995. John's wisdom. Louisville, KY: Westminster John Knox. 